IIUC STUDIES

ISSN 1813-7733

Vol.- 7, December 2010

(Published in December 2011) (p 131-146)

\title{
CLT Classrooms: Teachers' Role \& A Bangladesh Perspective
}

\author{
Sawsan Tarannum*
}

\begin{abstract}
This paper is designed to look at the role of teacher talk and teacher-student interaction in the management of communicative English learning. In particular, the focus is given on the activities of the teachers in a communicative English language classroom. For the organization of the classroom, teacher talk is of crucial importance. The language which teachers use is important for the organization and management of a communicative English language classroom, because it is the medium through which teachers either succeed or fail to implement their teaching plans. In this paper I have tried to discuss the role of a teacher in a communicative way. Teachers have to play different roles in CLT classrooms; therefore I will focus on their functions in general and their problems in the context of Bangladesh in particular.
\end{abstract}

\section{Introduction:}

Communicative Language Teaching (CLT) tends to concentrate almost wholly on the individual learner's needs and deficiencies. According to Richards and Rodgers (1986), CLT starts with a theory of language as communication, and its goal is to develop learners' communicative competence. Thus the teacher-dominated view in the domain of second language teaching has been shifted to the learner-centered perspective. While the emphasis in CLT is on the individual learner as the focus of learning, it has to be remembered that the teacher is still the person especially trained to guide the learner, help him/her select appropriate learning materials, and create a positive classroom environment. Today the role of teachers in the classroom is not like that of the

\footnotetext{
* Lecturer in English, Centre for University Requirement Courses (CENURC), IIUC.
} 
grammar-translation or audio-lingual methods which was a "combination drill sergeant and orchestra conductor" (Silberstein 1987, p.32). In the audio-lingual method, teaching was relatively easy as most activities were well programmed and ready-made. However, today he/she has to act as a facilitator of learning. Hence, today's communicative language teacher has to adopt and manipulate various roles ascribed to him/her. This paper is an attempt to look at the role of teachers in CLT classrooms, their use of language, how they manage different roles in a communicative way, the initiation of CLT in the secondary and higher-secondary levels in Bangladesh, and the problems faced by the post-primary teachers. In the first part of this article, I will try to focus on meaning of CLT, attributes of a CLT teacher, classroom activities in CLT, traditional teacher role as well as changing role in CLT, managing those roles, classroom language, importance of feedback, etc.; and in the second part, I will discuss, in brief, the CLT situation in Bangladesh.

There has been a prominent shift within the field of language learning and teaching in the late 1960s with greater emphasis being put on learners and learning rather than on teachers and teaching. In parallel to this new shift of interest, how learners process new information and what kinds of strategies they employ to understand, learn or remember the information have been the primary concern of the researchers dealing with the area of language learning. Since language classroom is like a problem-solving environment in which language learners are likely to face new input and difficult tasks given by their instructors, teachers' role to find the quickest or easiest way to adjust to what is required in a CTL classroom is inescapable. Before we go to further elaboration of teachers' role, we need to have a look at the meaning of CLT.

\section{Meaning of CLT}

CLT is usually characterized as a broad approach to teaching, rather than as a teaching method with a clearly defined set of classroom practices. As such, it is most often defined as a list of general principles or features. One of the most recognized of these lists is David Nunan's (1991) five features of CLT:

- An emphasis on learning to communicate through interaction in the target language.

- The introduction of authentic texts into the learning situation. 
- The provision of opportunities for learners to focus, not only on language but also on the Learning Management process.

- An enhancement of the learner's own personal experiences as important contributing elements to classroom learning.

- An attempt to link classroom language learning with language activities outside the classroom.

These five features are claimed by practitioners of CLT to show that they are very interested in the needs and desires of their learners as well as the connection between the language as it is taught in their class and as it used outside the classroom. Under this umbrella definition, any teaching practice that helps students develop their communicative competence in an authentic context is deemed an acceptable and beneficial form of instruction. Thus, in the classroom CLT often takes the form of pair and group work requiring negotiation and cooperation between learners, fluency-based activities that encourage learners to develop their confidence, role-plays in which students practice and develop language functions, as well as judicious use of grammar and pronunciation focused activities. CLT has brought a wide variety of changes in the attributes of teachers' activities in the classroom.

\section{Attributes of a CLT teacher}

The communicative language teacher aiming at training his/her students in using language learning strategies should learn about the students, their interests, motivations, and learning styles. The teacher can learn what his/her students already appear to be using, observing their behavior in the class. Do they ask for clarification, verification or correction? Do they cooperate with their peers? Besides observing their behavior in the class, the teacher can prepare a short questionnaire so that students can fill in at the beginning of a course to describe themselves and their language learning. Thus, the teacher can learn the purpose of their learning a language, their favorite / least favorite kinds of class activities, and the reason why they learn a language. The teacher can have adequate knowledge about the students, their goals, motivations, language learning strategies, and their understanding of the course to be taught (Lessard-Clouston 1997). It is a fact that each learner within the same classroom may be of different merits: if one is a mixed ability student, another can be the same ability student. The teacher cannot attribute importance to only one group. The communicative language teacher should, therefore, be 
expert to play a wide range of roles in order to meet the needs and expectations of his/her students. Therefore, it can be stated that the most important teacher role in CLT classroom is to adopt different roles to meet varied learner needs (Hall 1997).

The communicative language teacher should also study his/her own teaching method and overall classroom management. Analyzing his/her lesson plans, the language teacher can determine whether his/her lesson plans give learners chance to solve their problems by themselves or not. The teacher can see whether his/her teaching allows learners to approach the task at hand in different ways or not. The communicative language teacher can also be aware of whether his/her teaching is implicit, explicit, or both. It should be emphasized that questioning himself/herself about what he/she plans to do before each lesson and evaluating his/her lesson plan after the lesson in terms of strategy training, the teacher can become better prepared to focus on his/her teaching in a CLT classroom (Lessard-Clouston 1997).

\section{Common classroom activities in CLT}

The common roles of a CLT teacher are that the teacher prepares lessons, selects materials and activities, directs the lessons, coordinates the pupils' behavior, etc. The teacher transmits knowledge, passes on certain language facts, and informs the learners about rules and meanings. The teacher controls the students, monitors their interactions, disciplines them, checks homework, provides ideas, words, etc. that they may want to use in interaction. The teacher teaches the students how to learn, trains the students in strategy use, promotes independence, participates in activities as a partner and cocommunicator. The teacher not only exhibits proficiency in the target language but is able to answer the learners' unexpected questions. $\mathrm{He} /$ she evaluates the students' performance and progress correcting their mistakes and providing feedback. The teacher tries to make the atmosphere in the classroom pleasant, and maintains friendly relationships with the learners. He/she is not only interested in the students' linguistic development, but as a human being can help them in their personal problems. He/she serves as a model for behaviour, inculcates values and shapes the pupils' personalities, and teaches about the world. The teacher activates the learners' participation by arousing their interest.

As an extension of the notional-functional syllabus, CLT also places great emphasis on helping students use the target language in a variety 
of contexts and on learning language functions. Its primary focus is on helping learners create meaning rather than helping them develop perfectly grammatical structures or acquire native-like pronunciation. This means that successfully learning a foreign language is assessed in terms of how well learners have developed their communicative competence, which can loosely be defined as their ability to apply knowledge of both formal and sociolinguistic aspects of a language with adequate proficiency to communicate.

Communicative approach is not a highly structured method of teaching; rather it is a broad assembly of ideas from a range of sources which have come to be accepted as good practice by many contemporary teachers. It focuses on language as a medium of communication, and recognizes that all communication has a social purpose. In Bangladesh, the teachers face multifarious problems in managing their classrooms. Often the classroom is too big for them to control; sometimes the number of students is more than that is ideal for a communicative classroom. The government has initiated CLT without rendering proper training to the teachers who are familiar with traditional method. We have shortage of skilled as well as trained teachers in CLT (Communicative Language Teaching). A classroom is the center where individual learning processes occur, are nourished, and occasionally fail. Learning of a second/foreign language cannot be explained without studying the learner, the product, and the circumstances together.

The role of a teacher in such situations includes giving information, facilitating the activities, handing out resources, asking for feedback, dealing with behaviour, dealing with classroom errors, setting pairs and groups, managing time, evaluation issues, monitoring teaching, that is, teaching which makes the learners' needs and experience central to the educational process. In this sense, students' needs should be the driving force behind the rationale of syllabus design. Students' learning experiences and their responses to the syllabus should be at the heart of a language course. Kahlil Gibran writes: 'If (the teacher) is indeed wise, he does not bid you enter the house of his wisdom, but rather leads you to the threshold of your own mind' (Gibran 1991, p. 76). The implementation of this trend is to be found in classrooms where learners are given task to work on, and where real learning takes place. 'In these situations the teacher is no longer the giver of knowledge, the controller, and the authority, but rather a facilitator and a resource for the students to draw on' (Harmer 2001, p. 57). 


\section{Traditional Role of Teachers}

Now, we will have a look at the traditional role of teachers before the initiation of CLT:

Model of Language: In grammar-translation classrooms, language teaching is understood as the transmission of a linguistic system. In this transmission setting, the teacher provides the model to which students aspire, usually in terms of knowledge of syntax. Correct form and accuracy are more important than the content or messages.

Lesson Planner: During the last few decades of language teaching, more often it is the teacher, not students, who decides what and how the students will learn. Nunan (1988) has advocated planning and needs analysis as a teacher role, pointing out in his Learner-Centred Curriculum that if needs analysis shows learners not seeing the importance of communicative activities, then "Somehow or other, the teacher . . . needs to convince learners of the value of communicative activities" (Nunan 1988, p. 96). Again, it is clear that the issue is not so much to pay attention to the needs that students express, but to impose upon learners the idea that the teacher knows best.

Presenter of new language material: The stage of a lesson where learners focus their attention on text is often termed input. In this case, the teacher assumes responsibility for introducing the language. According to Byrne (1986, p. 2), the teacher is the center of activity at this point.

Controller of student practice: Traditionally, teachers observe students' performance, take notes of student errors, and correct student errors by themselves. If students make any error, teachers tend to correct it instantly rather than highlight it in a whole class discussion. Therefore, teachers have direct control on what students practise in the class.

Classroom Manager: In the grammar-translation method, a teacher takes control of the class. He/she speaks all the time while students remain passive. Wright (1987) contrasts the management behavior of teachers as "transmission" and "interpretation" (Wright 1987, p. 63) in several ways. A transmission teacher maintains a high degree of control over learners while the interpretation teacher maintains control by persuasion. In relative terms, the management of Wright's interpretation teacher is much more learner-centered than that of his transmission teacher. 
It is common to find binary distinctions being made between different general types of classroom. The dichotomies often appear like this:

\begin{tabular}{|l|l|}
\hline Traditional & Progressive \\
\hline Teacher centred & Learner centred \\
\hline Transmission teaching (telling) & Constructivist learning (discovering) \\
\hline Lock-step & Collaborative \\
\hline Grammar translation methodology & Communicative methodology \\
\hline
\end{tabular}

Alternatively, Alexander (2005, p. 28) suggests that there may in fact be at least six different classroom 'paradigms' around the world:

1. Teaching as transmission: inculcating information and skills deemed socially or economically necessary;

2. Teaching as initiation: giving learners access to the culture's stock of high-status knowledge (maths, science, literature, history, the arts etc) and enabling them to use its modes of enquiry and ways of making sense;

3. Teaching as negotiation: enacting the democratic principle in teaching; seeing knowledge as fluid rather than a fixed, created afresh rather than handed down; treating teachers and pupils as joint enquirers;

4. Teaching as facilitation: respecting and nurturing individual differences; responding to developmental needs rather than the social imperatives; and the pupil's readiness rather than the teacher's timetable; facilitating rather than directing;

5. Teaching as acceleration: outpacing individual development rather than following it; moving forward collectively towards common goals. Bridging the 'natural' and 'cultural' lines of development; and Teaching as technique: focusing on the teaching act rather than its underlying views of knowledge or the learner; emphasizing structure, graduated tasks, economy, conciseness and pace in teaching (thus striving towards efficiency).

\section{Role of teachers in CLT}

The role of a teacher in a CLT classroom is not static, rather dimensional. He/she has to play various roles in different situations. $\mathrm{He} / \mathrm{she}$ has to be innovative and imaginative. Within the classroom, a teacher's role may change from one activity to another or from one stage of an activity to another. If he/she is prompt in making these 
changes, his/her effectiveness as teacher is greatly enhanced. Teachers in learner-centered classrooms need special qualities including maturity, intuition, educational skills, an openness to student input, and a greater tolerance of uncertainty. These qualities are in marked contrast to more traditional teacher behaviour.

It is best for the teacher to keep standing most of the time so that the students can clearly see the teacher. It is a good idea to go round the class when students do group/pair work. Eye contact is always a good weapon to be used for interaction. Sometimes eyes of a teacher can indicate who will answer the question. The easiest way to check whether students have understood what the teacher has said is by looking at their face. The teacher may use his/her hands to avoid unnecessary language or to keep classroom less noisy. While directing the class, he/she should appear confident and bold. In making groups, he/she should always try to keep a good student in each group to ensure that group interaction is productive. He/she should check students understanding after discussing every new topic. Classes where students sit in straight rows are easier to control. The teacher should speak very slowly and clearly and behave as parents and friends in a large English class. When working in groups, the teacher should never do or say anything that the students can do or say themselves. Next, I will focus on the role of teachers in CLT classrooms.

Controller: When a teacher is in charge of the class, he/she has to play the role of a controller. A controller takes the roll, gives instructions to the students, organizes drills, and also reads aloud. Jeremy Harmer (2001) opines that ' of course there are times when acting as a controller makes sense such as when announcements need to be made, when order has to be restored, when explanations are given, or when the teacher is leading a question and answer session. Indeed in many educational contexts this is the most common teacher role' (Harmer 2001, p. 58).

Organizer: A teacher has to do various activities in order to organize his/her class effectively. He/she has to say what students should do first, what they should do next, etc. and deliver his/her instructions in a logical and unconfused way. 'It is vitally important for teachers to get this role right when it is required. If the students do not understand what they are supposed to do, they may well not get full advantage from an activity. If we do not explain clearly the ways pairs or groups should be organized, for example, the classroom will be chaotic. If we 
have not spent some time engaging the students' interest and ensuring their participation, the activity may be wasted' (Harmer 2001, p. 59). It is often a good idea to get students to give the instructions back in order to check whether they have understood it. Organizing a demonstration is always a useful means for the teacher to instruct his/her students. A teacher can organize the class in the following way:

Engage $\rightarrow$ instruct (demonstrate) $\rightarrow$ initiate $\rightarrow$ organize feedback (Harmer 2001, p. 59).

Assessor: A teacher assesses students' performance by offering feedback and correction and grading them in various ways. Students always expect that their teacher must provide them an indication of whether they are getting their English right or not. 'Students need to know how and for what they are being assessed. We should tell them what we are looking for and what success looks like so that they can measure themselves against this. We might say, for example, that in today's piece of writing I will be looking especially at punctuation or in this communication activity I am more interested in your fluency than your accuracy. Students then have a clear idea of what they need to concentrate on'. (Harmer 2001, p. 60)

The teacher should criticize positively for an equally good or bad performance because students generally want credit for good performance and constructive criticism for poor performance. They just do not like to be embarrassed in front of the whole class. When a teacher acts as an assessor, he must be sensitive to the students' possible reactions. Instead of pointing at the individual student's mistake, a teacher can expose it through a general discussion. The student will then feel at ease and get inspiration for further learning.

Prompter: Sometimes the students cannot proceed productively due to the lack of vocabulary. At this stage, they become unable to translate their thoughts in their scripts and they may not be quite sure how to proceed. What will be the teacher's role in such situations? He can obviously play the role of a prompter as he has to promote the students' proceedings. Harmer (2001) rightly says that 'In such situations we want to help but we do not want, at that stage, to take charge because we are keen to encourage the students to think creatively rather than have them hang on our every word. Thus it is that we will occasionally offer words or phrases, suggest that the students say something (e.g. well, ask him why he says that), or suggest what could come next in a paragraph a 
student is writing, for example. Often we have to prompt students in monolingual groups to speak English rather than using their mother tongue' (Harmer 2001, p. 60).

Participant: Jeremy Harmer (2001) points out that 'The traditional picture of teachers during student discussions, role-play, or group decision-making activities, is of people who 'stand back' from the activity, letting the learners get on with it and only intervening later to offer feedback and/or correct mistakes. However, there are also times when we might want to join in an activity not as a teacher, but also as a participant in our own right' (Harmer 2001, p. 60). There are many reasons why a teacher should take an active part in a discussion. While playing the roles like prompter, controller, or organizer, the teacher helps his/her students from outside, but in playing the role of a participant he/she helps them from the inside. The students enjoy having the teacher with them and the teacher also finds great enthusiasm. Thus the interaction between the teacher and the student becomes more flexible and more informal. At the same time, it has to be remembered that while participating in such discussions the teacher can easily dominate the proceedings because the teacher usually has more English at his/her disposal than his/her students. He/she can handle this situation through his/her skill and sensation.

Resource: In preparing a piece of group writing or a presentation, students may consider the teacher's direct interference entirely unwanted, rather they want him/her play the role of a resource. 'Students might ask how to say or write something or what a word or phrase means. They might want to know information in the middle of an activity about that activity or they might want information about where to look for something - a book or a web site for example. This is where we can be one of the most important resources they have' (Harmer 2001, p. 61). While acting the role of a resource a teacher must prove himself/herself helpful and available to the students, and great cautions need to be taken just not to make the students overreliant on him.

Tutor: A teacher can act as a tutor when students work with descriptive writing and with preparations for a talk or a debate. He/she needs to go to the individual students or small groups and try to point them in directions they have not yet thought of taking. This is a combined role-play of prompter and resource. It is difficult to play this role in a very large group as this activity includes a close relationship 
with the students. He/she has to go to many individuals or groups and keep him/herself visible to the whole class, otherwise he/she will lose his/her control over the class.

Monitor: The teacher goes round listening to pairs, which are asking and answering questions. Teachers need to pay attention to the amount and type of talking they do, and to evaluate its effectiveness in the light of their pedagogical objectives. Questions are extremely important, and teachers need to monitor the types of questions they ask. Another important consideration is wait time, that is, the thinking space teachers give to students between asking a question and demanding a response. Feedback and error correction are other important aspects of teacher talk. Teachers need to monitor, not only how and when such feedback is provided, but also whether the feedback is positive or negative, and who receives the feedback.

\section{Performing different roles: Teachers' activities}

What the teachers need is to be able to switch between the various roles described here, judging when it is high time to use one or the other. And then, they need to be aware of how they carry out that role and how they perform. At times, they may stand at the front commanding or entertaining. Sometimes they can work quietly with a pair while the other students work in their own group. The table given below shows how they might describe different activities:

\begin{tabular}{|ll|}
\hline Activity & How the teacher should perform \\
$\mathbf{1}$ Team game & energetically, encouragingly, clearly, fairly \\
$\mathbf{2}$ Role-play & clearly, encouragingly, retiringly, supportively \\
$\mathbf{3}$ Teacher reading aloud & commandingly, dramatically, interestingly \\
$\mathbf{4}$ Whole-class listening & efficiently, clearly, supportively \\
\hline
\end{tabular}

Figure: Describing teacher performance styles (Harmer 2001, p. 64)

They need to be careful of how much they themselves speak. If they speak all the time, however comprehensible their language is, the students are denied their own chance to practise production. They may also become bored by listening to the teacher all the time.

The teacher has to check constantly how communicative his/her class is. If he/she checks it frequently, he/she will get a comprehensive idea of the students' understanding. 


\section{Classroom language for teachers in CLT:}

David Nunan (1991) mentions that 'when talking to second language learners, teachers should try to use elaborated rather than simplified language. In other words, they should try to build in redundancy through the use of repetition, paraphrase and rhetorical markers rather than simplifying their grammar and vocabulary'. (Nunan 1991, p. 191)

There are two main ways in which English can be used in the class. Either it can be used in teaching the lesson itself: giving examples, introducing a text, asking questions, etc. or it can be used for activities which 'sound' the lesson, but which are not actually part of teaching: checking attendance, controlling the class. In this respect, the following three questions can be taken into account:

1. What advantages are there in using English as the main language of communication in the classroom?

2. What difficulties might we face using only English?

3 . How can these difficulties be overcome?

The answer to these questions can make us understand the value of using English in classroom. Firstly, if the teacher uses English most of the time, it will give students practise in listening and responding to spoken English. This will help them pick up words and expressions beyond the language of the textbook. Secondly, the teacher may not be able to speak English all the time and students may not be able to understand. The understanding ability of the students may well differ from student to student. It will take a long time to explain the meaning or use of a new word in English. Thirdly, even with a class of beginners starting their first English lesson, it is possible to teach entirely in English. For example, the instruction 'would you close your books, please?' At this stage, the teacher can give a clear demonstration. The teacher can pick up a book from his desk and close it as he gives the instruction. If only a few students understand and obey, they should be praised 'Good, you have closed your books'. At this stage, the other students, perhaps a bit slower, will have understood and obeyed. This is called 'display questions' (Nunan,1991, p. 194). If there are still students who do not understand, the instruction can be repeated. The teacher should not get angry with students who do not understand. Appreciation and encouragement are much more valuable tools for the teacher than anger and punishment, particularly when students are being asked to 
do something new. Elicitation is another common feature of classroom teacher questions. Elicitation methods are designed to extract information from students which might otherwise have been provided by the teacher.

\section{Providing Feedback}

To give instructions to students and to provide feedback on performance are the two most commonly conceived classroom activities of teachers. Feedback can be classified in various ways, such as positive and negative feedback. "For many years, behaviouristinspired research has found that positive feedback is much more effective than negative feedback in changing pupil behaviour. Positive feedback has two principal functions: to let students know that they have performed correctly, and to increase motivation through praise" (Nunan,1991, p 195). Nunan (1991) further mentions:

It is important that we develop an awareness, not only of the ways in which we Provide feedback to learners, but also we monitor who gets the feedback. It is clear from research that teachers, in general, are not aware of the signals they transmit to individual students. (Nunan 1991, p. 197).

It is quite usual that a teacher must provide corrective feedback in the classroom because learners expect feedback from their teacher. Investigations on classroom management also show that error correction by the teacher is one of the most highly valued and desired classroom activities. Gattegno's (1972) opinion in this regard might have been an example:

In my approach, I do not correct learners; I only throw them back onto themselves. To elaborate further their criteria and to use them more completely. Against a common teachers' demand for immediate correctness through so-called imitation, I take upon myself the burden of controlling myself so as not to interfere. By doing so I give time to a student to make sense of 'mistakes' .... (Gattegno 1972 p. 31)

A teacher has to say many things simply to organize the lesson starting or stopping an activity, getting students to do or not to do things, etc. Much of this language consists of simple commands and 
instructions, which are repeated lesson after lesson. So if the teacher says them in English, students will quickly learn what they mean. $\mathrm{He} / \mathrm{she}$ can elicit a range of simple classroom commands in English, which could be used even with elementary students. Some of them are given below:

$\begin{array}{ll}\text { Stand up, please } & \text { Open/ close your books } \\ \text { Sit down, please } & \text { Stop talking } \\ \text { Look! Look at me } & \text { Come here, please } \\ \text { Listen! } & \text { Come to the front, please } \\ \text { Repeat! } & \text { Be quiet, please } \\ \text { Again! } & \end{array}$

\section{CLT: A Bangladesh perspective}

The Communicative Language Teaching or CLT was introduced in Bangladesh in the late $90 \mathrm{~s}$ without strengthening the infrastructure. The teachers did not get any training to transform themselves from traditional to communicative method. As a result, they could not come out of their previous traditional outlook and remained unchanged. Majority of the teachers of our country have been used to teaching their students in the traditional method for ages. When they started teaching CLT with a traditional outlook, they made the whole lesson a mess. And the classroom has become a dull, uninteresting and fatigue place to the learners.

To be successful in CLT, a teacher must change his/her attitude and cope with the growing needs of new approach. Moreover, we have the scarcity of teachers and classrooms in comparison with the students. The traditional teachers have to go through one class after another just like a machine without knowing the outcome of the class. They are always in a hurry, so they take classes only for classes' sake. They cannot resist themselves from talking all the time in the classroom as they are used to it for a long time.

On the other hand, the CLT emphasizes the active role of the students in the classroom where they will speak more than the teachers. To be a communicative teacher, a traditional teacher needs to come out from his/her traditional attachments. To make the teachers familiar with the changing roles of CLT, the government has immense role to play. Short and long term training programmers can be arranged to make the 
teachers well acquainted with CLT. All the teachers of the country need to cope with this new approach, otherwise the initiation of CLT in the context of Bangladesh will be futile and the waste of time and money. It is a matter of hope that the NGOs like BRAC and ASA have already inaugurated training modules for the non-government school teachers. The PACE (Post-Primary and Continuing Education) program of BRAC has been contributing a lot, in spite of some limitations, to the development of non-government communicative language teachers. But it is not possible for them to cover the whole country. The government as well as the NGOs and private organizations should come forward to solve this problem to a large extent.

An ideal CLT classroom should consist of 25-30 students. The number of students exceeding 30 will create problems to conduct a CLT classroom successfully. But our usual classroom consists of 80-100 students as there is acute scarcity of classrooms and teachers. Teachers cannot make pairs and groups as this makes the classroom noisy and also hampers the neighboring classroom. The teachers of other disciplines complain to the authority against the teachers of CLT. As this is their only means of livelihood, they do not dare continue it further. As the CLT teachers naturally gain popularity among students due to their interaction with them, this causes jealousy in other teachers.

A large classroom is typically noisy, and at times it appears really difficult to control. It is also difficult to check student's class work or home work, to remember students' names, to give personal attention to them and, above all, to assess them properly. The teacher does not get enough time to allow students to practise and, therefore, he cannot monitor them effectively. Moreover, the benches of our schools are not suitable for making pairs and especially for groups. Also, the classroom size is not helpful to conduct CLT classes. Majority of our school, college, and even university classrooms are not equipped with modern teaching aids such as OHP, Multimedia facilities, projectors, $\mathrm{CD} / \mathrm{VCD}$ facilities, LCD monitors, etc. Many institutions are still using age-old blackboard and chalk for conducting classes. They even do not have whiteboard and marker facilities. A large number of our students do not have any access to computer. For that, the government should establish more schools, renovate existing schools, increase the number of classrooms, provide more and more equipment, impart training to the current teachers, recruit more trained teachers, offer rewards for the successful teachers and encourage different organizations to arrange training programmes. 


\section{Conclusion}

In this paper, I have focused on the role of a teacher and, in particular, on teacher language in a communicative English language classroom. Special preference is given to the amount and type of teacher talk, teacher questions, feedback, instructions and explanations. Teacher action and teacher-learner interaction are important aspects of CLT classroom, and there are many facets to structuring and managing learning. A comparative study between traditional teacher role and communicative language teacher role is drawn to make the discussion more comprehensive. Also, the scenario of CLT in the context of Bangladesh is discussed. However, all the teacher-roles mentioned in this paper are not possible and feasible to implement in the perspective of a country like Bangladesh where educational infrastructure is yet to groom.

\section{Works cited}

Alexander, R. Towards Dialogic Teaching: rethinking classroom talk. Dialogos: UK Ltd, 2005.

Byrne, D. Teaching Oral English. Essex: Longman, 1986.

Gattengno, C. Teaching Foreign Languages in School: The Silent Way. New York: Educational Solutions, 1972.

Hall, Stephen. "Language Learning Strategies: from the ideals to classroom tasks". Language and Communication Division, Temasek Polytechnic on Internet, 1997.

Harmer, Jeremy. The Practice of English Language Teaching. Cambridge: Pearson Education Ltd., 2001.

Kahlil, Gibran. The Prophet. Oxford: Oxford UP, 1991.

Lessard-Clouston, Michael. "Language Learning Strategies: An Overview for L2 Teachers" on The Internet TESL Journal,1997.

Nunan, David. Language Teaching Methodology: A Textbook for Teachers. New York, Prentice Hall, 1991.

Nunan, David. The Learner-centred Curriculum. Sydney: Cambridge UP, 1988.

Richards, J. C., \& Rodgers, T. Approaches and Methods in Language Teaching: A Description and Analysis. Cambridge: Cambridge UP, 1986.

Silberstein, S. "Let's Take Another Look at Reading: Twenty-Five Years of Reading Intruction". English Teaching Forum, 25, 4, 1987.

Wright, T. Roles of Teachers and Learners. Oxford: Oxford UP, 1987. 